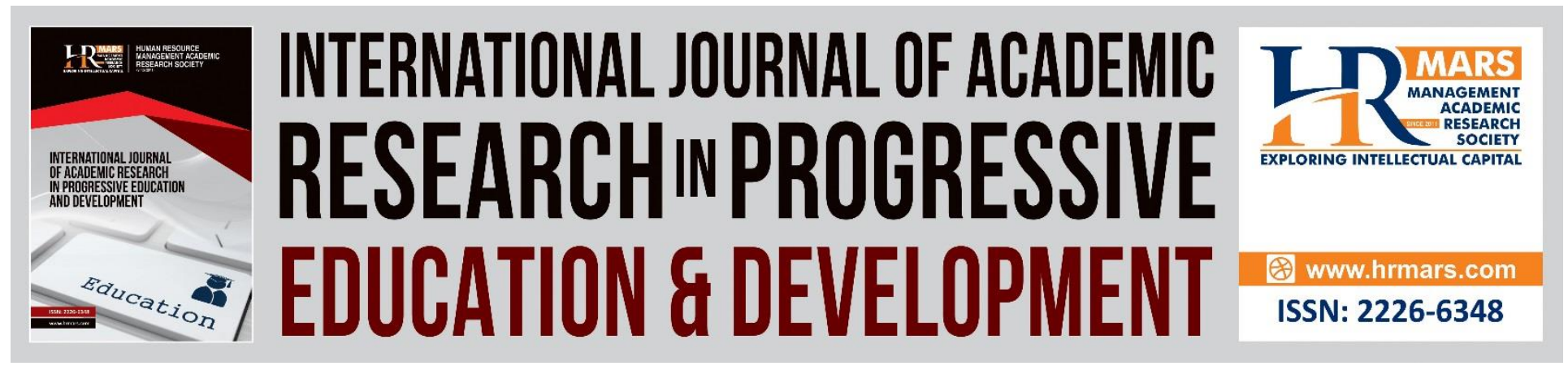

\title{
Relationship of Teaching Style Towards to Elementary School Achievement of Students
}

Najmi Hayati, Shahlan Surat, M. Ali Noer

To Link this Article: http://dx.doi.org/10.6007/IJARPED/v10-i2/9726

DOI:10.6007/IJARPED/v10-i2/9726

Received: 09 February 2021, Revised: 13 March 2021, Accepted: 28 March 2021

Published Online: 23 April 2021

In-Text Citation: (Hayati et al., 2021)

To Cite this Article: Hayati, N., Surat, S., \& Noer, M. A. (2021). Relationship of Teaching Style Towards to Elementary School Achievement of Students. International Journal of Academic Research in Progressive Education and Development, 10(2), 89-99.

Copyright: (c) 2021 The Author(s)

Published by Human Resource Management Academic Research Society (www.hrmars.com)

This article is published under the Creative Commons Attribution (CC BY 4.0) license. Anyone may reproduce, distribute, translate and create derivative works of this article (for both commercial and non-commercial purposes), subject to full attribution to the original publication and authors. The full terms of this license may be seen at: $\underline{\text { http://creativecommons.org/licences/by/4.0/legalcode }}$

\section{Vol. 10(2) 2021, Pg. 89 - 99}

Full Terms \& Conditions of access and use can be found at http://hrmars.com/index.php/pages/detail/publication-ethics 


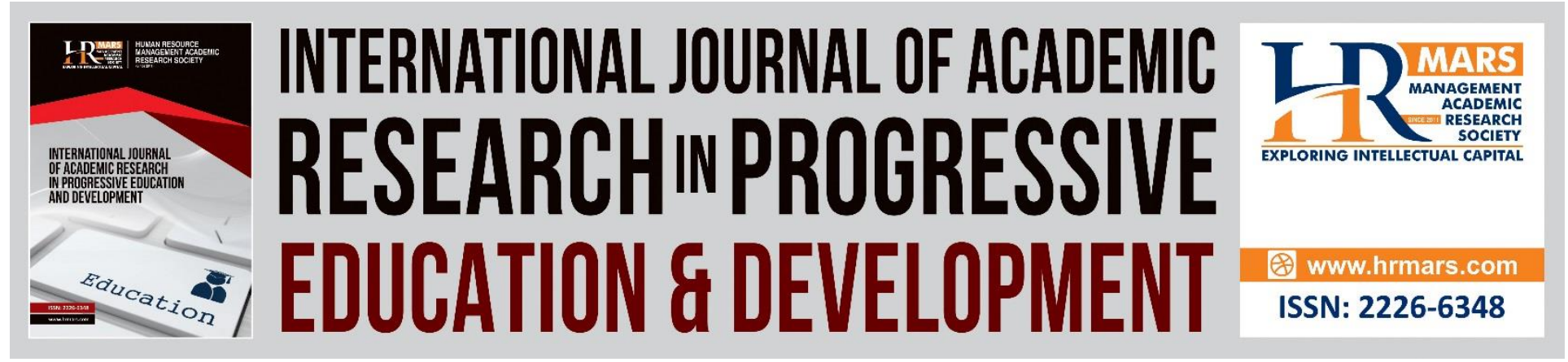

\title{
Relationship of Teaching Style Towards to Elementary School Achievement of Students
}

\author{
${ }^{1}$ Najmi Hayati, ${ }^{2}$ Shahlan Surat, ${ }^{3} \mathrm{M}$. Ali Noer \\ ${ }_{183}$ Institute for Research and Community Service, Universitas Islam Riau, \\ Indonesia, ${ }^{1 \& 2}$ Faculty of Education, Universiti Kebangsaan Malaysia, Malaysia
}

\begin{abstract}
This study took place in Pasir Pengarayan Rokan Hulu Regency, Riau Province, Indonesia. This study intends to identify the connection between teaching styles and student achievement at the sixth grade level of the Pasir Pengarayan elementary school. The respondents of this study were 40 elementary school sixth graders and 13 teachers who were picked out of the Pasir Pengarayan elementary school. This research employed a questionnaire review method. When student achievement declined, a number of teachers said their students felt uncomfortable in class and had low proficiency, which encouraged researchers to observe teachers from a teacher's point of view as well as from a student's point of view. To ensure that the teacher's teaching style is suitable for the learning style of students, consideration should be given to the teaching and learning process in the classroom. Grasha's teaching style model was used to determine the relationship between teaching styles, so the researcher used descriptive analysis by studying the mean value and inference analysis by looking at the manifestation of the Spearman correlation reliability value. The link between the teacher's teaching style and student achievement can be demonstrated using correlation and significance analysis, where the expert model shows a correlation of $r=0.701$ and a significance of 0.004 , thus implying Ho is rejected. Furthermore, the facilitator model's teaching style shows a relationship coefficient of $r=0.516$ and significance of sig $=0.001$, which means that $\mathrm{Ho}$ is rejected, in the sense that the facilitator model's teaching style has an impact on student achievement. Based on the dominance of the given value and the inference correlation value, it is assumed that the expert teaching model and the facilitator teaching model are applied by sixth grade teachers at the Pasir Penagarayan elementary school in front of their students, who have demonstrated their proficiency.
\end{abstract}

Keywords: Pasir Pengarayan, Teaching Style, Teacher, Student, Achievement.

\section{Introduction}

Education is a deliberate and planned attempt to build an environment of learning and the process of learning so that students successfully improve their capacity to have the 
spiritual strength, self-control, personality, intellect, noble character, and skills required for themselves, community, nation and state (UU SPN No. 20 of 2003).

In the context of the intellectual life of the nation, national education based on Pancasila and the 1945 Constitution of the Republic of Indonesia functions to grow professionally and shape the character and civilization of the nation with dignity, aiming to develop the opportunities for the students to become human beings who believe and fear God Almighty. Human beings have a noble character, are healthy, knowledgeable, capable, creative, independent and democratic and responsible citizens (Permendiknas no. 22 of 2006).

It emphasizes that the teaching process provided by the teacher is capable of providing human beings who have faith and devotion to God Almighty, have a noble character, are healthy, knowledgeable, capable, creative, independent, in the Laws and Regulations of the Minister of National Education above. In the classroom and outside the classroom, the teacher is the driving force and driving force of all teaching and learning processes. Teachers have to make a teaching plan that satisfy the requirements of learners, study groups and the entire educational setting. Every teacher has a preference or style for doing something. Style affects the person as an individual and distinguishes him from others. One of the most widely recognized applications is style related to the educational domain. In the realm of teachers, it is known as the teaching style and is defined as a favorite way for teachers to solve problems, carry out assignments, and make decisions in the teaching process (Giles et al., 2006).

The teacher can apply various strategies or teaching styles that are in accordance with a student learning strategy and style. It is better if the teacher needs to arrange the learning units in an order that is in accordance with the learning outcomes, examples starting from easy to difficult ones and ensuring the problems being taught are appropriate at the initial level or in the conditions. Every teacher must have high teaching skills, be knowledgeable in the subjects being taught, make various teaching strategies and be proficient in technology to produce an effective and optimal teaching and learning process. Teachers also need to pay attention to the level of intelligence of students. Different styles and activities need to be planned for students of different intelligence levels. Examples of visual and spatial intelligence, verbal linguistics, music and rhythm, mathematical logic, kinesthetics, social relations, the relationship between humans and their creators and understanding of the natural surroundings.

Easy-to-use teaching methods can be used in both traditional classroom environments and technology-assisted classroom environments. Maybe that is not what he applies perfectly in a traditional classroom environment but a classroom environment with diverse student intelligence can pay special attention to each student, teach based on his features, and behave flexibly (Brown, 2007). This difficulty in the traditional classroom environment can be helped to be eliminated through the technological environment. Creating a learning environment for each student based on learning characteristics in an e-learning environment, which is a product of technology, is easier than creating it in a traditional classroom environment (Park \& Choi, 2014).

In every condition the teaching and learning carried out by each teaching staff is unique and all subjects taught are different from one lesson to another. There are many teaching behaviors that are considered to be particularly impressive in some circumstances but perhaps less impressive in others. The teaching style of the teacher that is in accordance with the learning style of students will create a positive impression on the learning process of students in class. But 
if the teacher's teaching style is not consistent or the same as the learning style favored by students for a long time, it will cause or cause boredom in students.

The approach that is considered correct is not always appropriate for every student. Likewise with the teaching style. The way to convey teaching and learning is a reflection of the learning style and personality of a teacher. The strategy in mind should be in accordance with that followed by every student (Pin, 2001).

Teachers need to monitor the learning styles of each student by giving positive meanings to the students' abilities and efforts. Students will be able to easily follow and understand the teacher's teaching process if the teacher pays attention to the development and needs of students. This attention summarizes a positive attitude towards students 'abilities and efforts, understands the nature of students and provides fair service to students without discriminating against students' levels of intelligence and achievement.

Teacher style teaching is an important factor in influencing student motivation towards learning. This is because the teacher has a great influence on the attitudes and interests of students in learning. Meaningful learning arises from a feeling of interest among students and one way to generate student interest is to use interesting teaching strategies and learning activities. Indirectly, teacher teaching style that attracts students can increase student interest and motivate them to make better decisions as shown in the test results (Azlin, 2009).

The teaching and learning process that runs inside the classroom and outside the classroom is a complete complementary process and involves two parties, namely the teacher who controls the teaching and the students who undergo learning. Therefore the teaching and learning process will run smoothly if there is a relationship and commitment between the two parties, namely teachers and students in the classroom.

Based on the situation above, the researcher wants to see the teacher's teaching style and how this teacher's teaching style can foster the interest and enthusiasm of students' motivation towards increasing achievement in subjects in the sixth grade of the Pasir Pengarayan elementary school. Where Pasir Pengarayan is a district of the Riau Province on the Indonesian island of Sumatra, with a large population.

\section{Concept Teaching Style}

Style is the nature of a person that is influenced by environmental factors and natural factors, such as features. Style is a trait that is carried out by an individual in the performance of activities. Basically, teaching aims to lead students to achieve pre-planned objectives, and the teaching behavior shown by the teacher is very diverse in practice. When traced, the diversity of teacher behavior in teaching will gain an overview of the general interaction patterns between teachers, content, or learning materials and learners. This general pattern (in Irvine, 2003).

Teaching style is a form of teacher appearance when teaching, both curricular and psychological, according to Shaaria (2014). Teachers that teach tailored to the goals and characteristics of certain subjects are curricular teaching styles. Teaching styles that are psychological in nature are teacher teaching tailored to student motivation, class management and learning outcomes assessment.

According to Richards and Rodgers (2001), the teaching approach is a method of determining whether students quickly achieve their learning goals in his book, becoming an 
initiator teacher. Whether done in the form of group or individual teaching, a teaching style approach will be effective if it is in line with the goals, subject matter, and interests and needs of students.

The style of teacher teaching can be seen by delivering content in the classroom teaching and learning process. Teaching is defined by Dick and Reiser (1989) as an interaction that aims to increase the knowledge and skills of particular and predetermined students. At least seven aspects are included in the sequence of this teaching, namely motivating students, explaining what is learned, helping students remember previous knowledge, providing teaching materials, providing guidance and feedback, testing comprehension and providing stimulus and recovery.

Teachers who are good at educating will otherwise make it easier for students to understand a concept or ability, teachers who are not already good at educating or teaching will make it difficult for students to understand a concept or ability, instead it will make teacher teaching boring on the perceptions of students (Azlin, 2009). If boredom occurs in students, then there are signs of school problems and problems in the classroom and this indirectly presents the teacher with a challenge.

The choice of strategy, including the wrong strategy for learning control, will be a factor that will cause learners to lose interest and feel bored. In order to realize awareness of their respective responsibilities, teaching and learning practices in the classroom today need to undergo a transformation of educational practices that are more creative and productive, critical and innovative, including those of aspects of psychology between teachers and students.

Grasha (1996) clarifies that teachers who believe in teaching will be more interested in establishing good student relationships. The teaching and learning process is made easier and more enjoyable by a good relationship between teachers and learners because there are no distractions or disciplinary problems carried out by students in the classroom.

Through his book "teaching with styles" by Grasha (1996), eight aspects that are often related to the style of teaching are clarified, namely;

1. The dimension of teaching - the concept of intellectual pleasure and behavior of individuals.

2. The characteristics or characteristics of a great teacher - the personal characteristics of teachers, such as teachers who have been successful in teaching before.

3. The teaching approach employed in the classroom is the teaching strategy selected.

4. General actions of the teacher or universal behavior of the teacher.

5. The position of the teacher in the class is the teaching consequence in the classroom.

6. The teacher's personal character, namely the findings of observations and interviews.

7. Focus on teachers, students and educational content and concentrate on teaching.

8. Metaphors concerning teaching or forms of teaching.

When the teaching and learning process takes place, teachers must be wise and capable of creating a classroom atmosphere full of fun and actively involving all students. In order to encourage them to be interested in learning a subject, teachers also need to manifest high curiosity among students. After success, teachers need to develop different ways to maintain the attention and interest of students in learning (Noor \& Jamaludin, 2011).

The character, authority and knowledge of the teacher are an important basis for evaluating the quality and goodness of science itself in the digestion of knowledge that generates progress. Scientific teachers are teachers who are knowledgeable, dedicated and sincere in 
spreading knowledge solely through the power of enthusiasm, awareness and dedication because of Allah. Knowledge that is a little better devoted to than a lot of knowledge, but only stored, "Knowledge that is a little better devoted to than a lot of knowledge, but only stored" (Mohamad \& Hashim, 2010). A brilliant and world-class education system can be achieved in the future if science and skills are implemented perfectly, thoroughly and with a complete sense of responsibility by teachers to students in the implementation of teaching and learning.

\section{Method}

This study is a questionnaire correlation study and the researcher attempts to identify the dominant style of teaching conducted by teachers following the Grasha Teaching Style Model in elementary schools in Pasir Pengarayan. Researchers also looked into whether there's any correlation between a teacher's teaching style and a student's academic performance.

The participants in the study were Pasir Pengarayan Elementary School sixth graders. The researcher selected 40 students as participants for this study, consisting of 20 students in the 6A class and 20 students in the 6B class. There were up to 13 teachers who responded to the survey. This choice of school is considered to be capable of representing the participants that the researcher needs. The researcher wanted to see if there was a correlation between teacher teaching styles and student achievement perceptions in this study.

instead of conducting appropriate research and testing with a small sample of respondents to see if the research tools need to be adjusted or changed (Creswell, 2005). This test is used to assess the validity and reliability that will be used in the field to collect data. The validity of a study indicates whether it has a survey tool that measures what should be measured, whereas reliability refers to the consistency of indicators and the research tool's stability (Jackson, 2006).

A total of 10 Pasir Pengarayan Elementary School sixth grade students and 2 Pasir Pengarayan Elementary School teachers were asked to reply in August 2019 to a questionnaire related to the Grasha Teaching Style Inventory. Respondents were chosen at random for this test, and their backgrounds were adjusted to be similar to those of respondents to a field study. The instrument testing results were found to have a high reliability index and were deemed appropriate for the teacher's teaching style, as shown in table 3.3 below.

Table 3.3 Alpha value of Cronbach on each questionnaire statement

\begin{tabular}{c|c|c}
\hline No. & Alpha Value & Number of items \\
\hline 1 & 0.763 & 40 \\
\hline
\end{tabular}

There are indeed two types of analysis in the analysis process: descriptive and inference analysis. Besides looking at the frequency and percentage values, descriptive analysis can be used to describe demographic factors. If the mean and standard deviation interpretation is used to recognize the dominant teaching method on the academic achievement of the studied students between the five teaching styles of the studied teachers. The analysis of correlation also provides a coefficient that can be used to measure the strength of the relationship between the two variables under study as an index. The strength and direction of the relationship between two 
Vol. 10, No. 2, 2021, E-ISSN: 2226-6348 @ 2021 HRMARS

variables, namely teachers and student achievement, is assessed using Baba (1997)' interpretation of the correlation coefficient $r$.

\section{Result and Discussion}

\section{A. Descriptive Analysis}

The Teaching Style of Class Six Elementary School Teachers Follow Students' Perceptions

In order to ascertain the teaching style of sixth grade elementary school teachers following student perceptions, descriptive analysis was conducted involving mean and standard deviation. The descriptive analysis' findings are shown in table 4.1 below.

Table 4.1 The teaching style of the sixth grade elementary school teachers follows the

\begin{tabular}{l|l|l|l}
\multicolumn{4}{c}{ students' perceptions } \\
\hline \multicolumn{1}{c|}{$\begin{array}{c}\text { Teacher teaching } \\
\text { style }\end{array}$} & Mean & \multicolumn{1}{|c}{ SD } & Interpretation \\
\hline Expert & 4.359 & 0.919 & High \\
Formal Authority & 4.272 & 1.599 & High \\
Personal Model & 4.088 & 0.387 & High \\
Facilitator & 4.041 & 0.360 & High \\
Delegator & 3.888 & 0.464 & High \\
\hline
\end{tabular}

The expert teaching style (mean $=4.359$ and $s d=0.919$ ), which is followed by the formal authority teaching style (mean $=4.272$ and $s d=1.599)$, the teaching style model personal (mean $=4.088$ and $s d=0.387$ ), and the facilitator's teaching style (mean $=4.041$ and $s d=0.387$ ), is the highest-ranking teaching style (mean $=4.359$ and $s d=0.919$ ). Explains that the teacher's teaching style is based on the learner's perspective, and that the most common teaching style used by the teacher is the expert teaching style. The delegate teaching style is then followed by the formal authoritative style of teaching, personal model, facilitator and teacher teaching style that is rarely used by teachers.

The Teaching Style of Sixth Grade Elementary School Teachers Follow the Perceptions of the Teacher

In order to determine the teaching style of sixth grade elementary school teachers following teacher perceptions, descriptive analysis was conducted involving mean and standard deviation. Table 4.2 summarizes the results of the descriptive analysis. 
INTERNATIONAL JOURNAL OF ACADEMIC RESEARCH IN PROGRESSIVE EDUCATION AND

DEVELOPMENT

Vol. 10, No. 2, 2021, E-ISSN: 2226-6348 @ 2021 HRMARS

Table 4.2, which depicts the teaching styles of sixth-grade elementary school teachers, reflects teacher perceptions.

\begin{tabular}{l|c|c|l}
\hline \multicolumn{1}{c|}{$\begin{array}{c}\text { Teacher teaching } \\
\text { style }\end{array}$} & Mean & SD & Interpretation \\
\hline Expert & 4.077 & 0.063 & High \\
Formal Authority & 3.894 & 0.112 & High \\
Personal Model & 4.019 & 0.100 & High \\
\hline Facilitator & 4.538 & 0.164 & High \\
\hline Delegator & 3.692 & 0.166 & High \\
\hline
\end{tabular}

According to the data, the facilitator teaching style (mean $=4.538$ and $s d=0.164$ ) is the most commonly used by teachers, followed by expert teaching style (mean $=4.077$ and $\mathrm{sd}=$ 0.063 ), personal model teaching style (mean $=4.019$ and $s d=0.100)$, formal authority teaching style (mean $=3.894$ and $s d=0.112$ ), and delegator teaching style (mean $=4.019$ and $s d=0.100$ ). It thus shows that the teaching style of the teacher's sixth grade elementary school teachers is the facilitator's teaching style, followed by the expert teaching style, personal models and formal authority, while the delegator's teaching style is the lowest teaching style used by the teacher.

\section{B. Inference Analysis}

Throughout order to clearly identify the correlation between teacher teaching styles and student perceptions with student achievement in grade six elementary schools, Spearman's correlation analysis was carried out.

Table 4.3 Spearman correlation of the relationship between teacher teaching style following student perceptions and student achievement.

\begin{tabular}{l|c|c|c}
\hline \multirow{2}{*}{\multicolumn{1}{c|}{ Relationship }} & \multicolumn{2}{|c|}{ Achievement } & \multirow{2}{*}{ Interpretation } \\
\cline { 2 - 3 } & $\mathrm{r}$ & Sig. & \\
\hline Expert & 0.701 & 0.004 & High \\
Formal Authority & -0.013 & 0.661 & - \\
Personal Model & 0.399 & 0.213 & - \\
Facilitator & 0.516 & 0.001 & Medium \\
Delegator & -0.062 & 0.557 & - \\
\hline
\end{tabular}

According to the data above, with a value of $r=0.701$ and sig $=0.004(<0.05)$, there is a statistically significant relationship between expert teaching style following student perceptions and student achievement. As a result, the hypothesis (Ho.1) that there is no significant relationship between expert teaching style and student achievement has been rejected. With a value of $r=-0.013$ and sig $=0.661(>0.05)$, there is no significant relationship between authoritarianism teaching style and student achievement. As a result, Hypothesis (Ho.2) is accepted, which states that there is no significant relationship between authoritarianism 
teaching style and student achievement. With a value of $r=0.399$ and sig $=0.213(>0.05)$, there is no significant relationship between the personal model teaching style based on student perceptions and student achievement. As a result, the hypothesis (Ho.3) is accepted, stating that there is no significant relationship between personal model teaching style and student achievement. With a value of $r=0.516$ and sig $=0.001(<0.05)$, there is a significant relationship between the facilitator's teaching style and student perceptions with student achievement. As a result, the hypothesis (Ho.4) that there is no significant relationship between the facilitator's teaching style and student achievement based on student perceptions is disproved. With a value of $r=-0.062$ and sig $=0.557(>0.05)$, there was no significant relationship between the delegator's teaching style and student perceptions with student achievement. Then the hypothesis (Ho.5) states that no significant relationship is accepted between the delegator's teaching style following student perceptions and student achievement.

From the above statistical analysis, it shows that there is no significant relationship between teaching styles following student perceptions and student achievement, namely formal authoritative styles of teaching, styles of teaching personal model and styles of teaching delegation. The hypothesis (Ho) demonstrates that there is no significant connection between the teaching style following the perceptions of students and the achievement of students.

Expert teaching style and facilitator teaching style, on the other hand, demonstrate that there is a significant relationship between teaching style and student achievement based on students' perceptions. The hypothesis (Ho) shows that there is no important connection between the teaching style following the perceptions of students and the achievement of students is rejected.

\section{Conclusion}

\section{The Teaching Style of Elementary Sixth Grade Teachers}

The expert model teaching style emerged as the most dominant among sixth grade elementary school students as a result of statistical analysis involving the teacher's teaching style based on the students' perceptions. Researchers can articulate that the teaching style of the expert model was selected because the teacher mastered knowledge, concepts and principles in teaching related to a subject topic and broad knowledge, high skills and focused teaching on knowledge information transmitted through lectures. In comparison to other teaching styles, this teaching style is used in the teaching and learning process, training, and workshops, and it is used at almost all levels of teaching.

The teacher himself demonstrates that the teacher has expertise in subjects that are concerned with providing meaningful lessons to students when delivering the content of good teaching material. This will inspire and encourage students to learn and try to be more persistent in the subjects presented by the teacher's teaching style. Through language, examples and treatment, the conduct demonstrated by the teacher can be learned. When compared to behavior that is based solely on punishment, students are more likely to imitate positive interactions and models.

The Relationship between Teacher Teaching Style and Student Perceptions and Student Achievement

The statement that not all teaching models can help students, so that every aspect of the teacher's teaching style is analyzed in detail, shows that the teaching style of the expert model 
and the facilitator model show a significant relationship with student achievement in the subject. It is impossible to deny the influence of the style of teacher teaching on student academic achievement. The failure of the teacher to use a style of teaching that is consistent with the stage of the ability of the student will cause students to become bored or will not pay attention to the teacher's explanation, and when the teacher teaches, it becomes the basis. As a result, students will fall behind in these subjects and, as a result, fail their exams. Teachers who have a style of teaching that suits the needs and stages of the development of student achievement in the classroom will help students accept the teaching and learning process well in the classroom. Teachers must also be aware that each student has a unique learning style, and it is necessary for the teacher to understand the student's learning style in order to match their teaching style in order for the student to succeed in a subject. Teachers not only concentrate on one teaching style on their teaching style, it would be better if when teaching in the classroom, the teacher combines several teaching styles to avoid student boredom. In this way, the increase in the knowledge and mastery of the subjects by students will be successful and can further improve the academic achievement of students in the subjects taught by the teacher. In this study, the authors recommend two issues as follows:

- $\quad$ Teachers must gain a better understanding of their teaching style by expanding their knowledge in order to match their students' learning styles.

- $\quad$ To help students learn at home, schools and teachers need to socialize this teaching style to student parents so that student learning will be more exciting in learning for them.

\section{Acknowledgement}

The author would like to express his thankfulness to the Riau Islamic University Research and Community Service Institute, which served as the primary sponsor for this study under contract No.236/Contract/LPPM-UIR/4-2018, as well as all of the teachers at Public Elementary School 010 Rambah Pasir Pengarayan, who assisted in providing space and facilitating the data retrieval process.

\section{Corresponding Author}

Institute for Research and Community Service, Universitas Islam Riau, Jl. Kaharuddin Nasution 113, Pekanbaru, Riau Province 28284, Indonesia

Email: najmihayati@fis.uir.ac.id

\section{References}

Azlin, N. B. J. (2009). Students 'perceptions of trade teachers' teaching styles. Master Thesis. faculty of Education. Universiti Kebangsaan Malaysia.

Brown, H. D. (2007). Principles of Language Learning and Teaching. USA: Longman

Baba, A. (1997). Research statistics in education and social sciences. Ed. 2nd. Bangi: Publisher. Universiti Kebangsaan Malaysia.

Creswell, J. W. (2005). Educational research: Planning, conducting, and evaluating quantitative and qualitative research (2nd ed.). Upper Saddle River, NJ: Pearson.

Dick, W., and Reiser, R. A. (1989). Teaching student to teach themselves. New York: Nicholas Publication. 
Grasha, A. F. (1996). Teaching with styles: A practical guide to enhance learning by understanding learning and teaching styles. New York: Alliance Publisher.

Grasha, A. F. (2002). Teaching with Styles: A Practical guide to Enhance Learning and Teaching Styles. New York: Alliance Publisher.

Giles, J., Ryan, D. A. J., Belliveau, G., De Freitas, E., \& Casey, R. (2006). Teaching style and learning in a quantitative classroom. Active Learning in Higher Education, 7(3), 213225. doi:10.1177/1469787406069055

Irvine, J. J. (2003). Educating Teacher for Diversity. Teacher College Press, Columbia University. Jackson, S. L. (2006). Research methods and statistics: A critical thinking approach (2nded.). Belmont, CA: Thomson Higher Education.

Mohamad, B., and Hashim, I. (2010). Teaching and Learning Styles. Kuala Lumpur: PTS Profesional.

Noor, N. M., \& Jamaludin, N. (2011). The effect of the use of Mechanical Engineering courseware on the teaching style of Mechanical Engineering teachers in Technical Secondary Schools in Terengganu. Journal of Technical, Vocational \& Engineering Education 2, 79- 92

Pin, O. C. (2001). Student learning style and teaching style of form two teachers in urban and rural secondary schools in Batu Pahat district, Johor. Bachelor Thesis. Universiti Teknologi Malaysia.

Park, E. L., \& Choi, B. K. (2014). Transformation of classroom spaces: traditional versus active learning classroom in colleges. Higher Education, 68(5), 749-771. doi:10.1007/s10734-0149742-0

Regulation of the Minister of National Education of the Republic of Indonesia Number 22. (2006). Concerning Content Standards for Primary and Secondary Education Units.

Richards, J.C., and Rodgers, T.S. (2001). Approaches and Methods in Language Teaching. Second Edition. Cambridge University Press.

Shaaria, A. S., Yusoffb, N. M., Ghazalic, I. M., Osmand, R., Dzahir. N.F.M. (2014). The Relationship between Lecturers' Teaching Style and Students' Academic Engagement. Procedia - Social and Behavioral Sciences. doi: 10.1016/j.sbspro.2014.02.002

Undang-Undang of the Republic of Indonesia Number 20. (2003). Concerning the National Education System. 